\title{
Distribution of Asian Chameleons (Chamaeleo zeylanicus Laurenti 1768) in Different Forest Types of Rajasthan, India
}

\author{
Satish Kumar Sharma ${ }^{1}$ and Vijay Kumar Koli ${ }^{*}$ \\ ${ }^{1}$ Assistant Conservator of Forests, Jaisamand Wildlife Sanctuary, Jaisamand Post Office, Udaipur 313 905, Rajasthan, India (sksharma56@gmail.com) \\ ${ }^{2}$ Wildlife Research Laboratory, Department of Zoology, University College of Science, Mohanlal Sukhadia University, \\ Udaipur 313 001, Rajasthan, India (vijaykoli87@yahoo.in) \\ *corresponding author
}

A sian Chameleons (Chamaeleo zeylanicus; Fig. 1) are known to occur in India, Sri Lanka, and Pakistan (Srinivasulu et al. 2014). In India, the species has been reported from the entire Indian Peninsula, including the Eastern and Western Ghats. It occupies scrublands, dry deciduous forests, and secondary forests (Tikader and Sharma 1992; Srinivasulu et al. 2014), but detailed ecological requirements and habitat studies are lacking. In the course of the last two decades, Gaur (2004), Bhatnagar and Mahur (2008), Bhatnagar et al. (2010), Sharma et al. (2011), and Sharma (2014) contributed new records of the species' occurrence in Rajasthan, where it occurs in the southern and central parts of the state, but is absent from the extreme north and the western parts of the state (Srinivasulu et al. 2014). Although Srinivasulu et al. (2014) listed the species as being of "Least Concern" in the IUCN Red List, it is rarely encountered in Rajasthan. Herein we present an overview of its distribution, status, new sighting records, habitat preferences, and vernacular names in Rajasthan.

Champion and Seth (1968) listed three types of forests in Rajasthan: Group 5 - Tropical dry deciduous forest (A), Group 6 - Tropical thorn forest (B), and Group 8 Subtropical broad-hill forest (C). From 2000 to 2016, we visited all three forest types to investigate the distribution of Chamaeleo zeylanicus in Rajasthan. Because chameleons are primarily arboreal, we emphasized scrublands, woodlands, and denser forested areas. Other than during the rainy season, chameleons are difficult to find; consequently, we conducted most of our surveys after the onset of the monsoons, when both males and females are encountered on the ground, where they are conspicuous when crossing blacktop roads. We noted the location where an animal was sighted, the forest type, and ethnozoological aspects of its presence via interviews with local people, who helped us define conservation issues.

This species has so far been documented in 12 Aravallian districts of Rajasthan (Table 1; Fig. 2), where it occurs

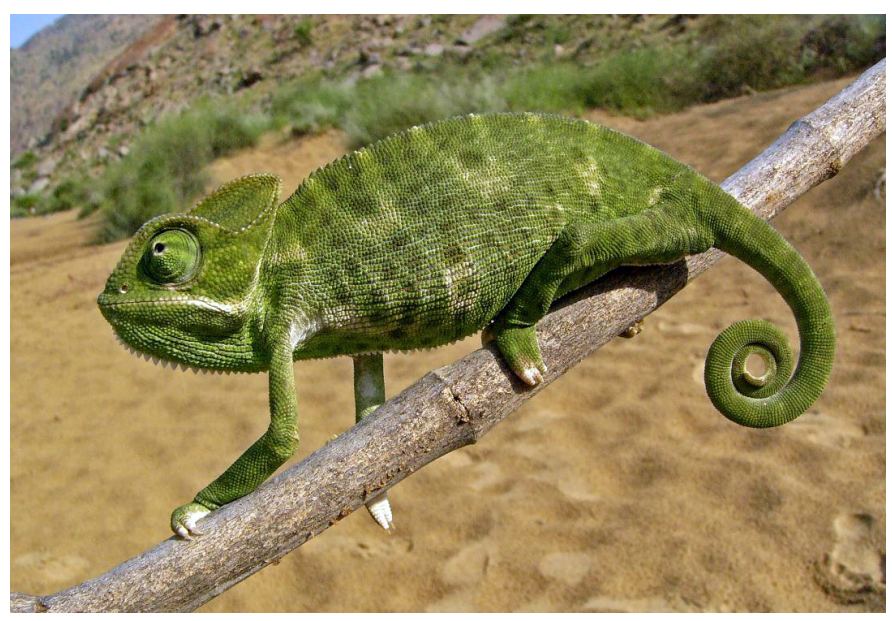

Fig. 1. An adult Asian Chameleon (Chamaeleo zeylanicus). Photograph by Dr. Dharmendra Khandal.

throughout the Aravalli Mountain Range from Udaipur to Sikar in tropical thorn forest and where tropical dry deciduous forest and subtropical broad-hill forests meet. Although present in all three forest types in Rajasthan, chameleons appear to be most abundant in tropical dry deciduous forest and tropical thorn forest and in areas where the two forest types meet. Tropical thorn forest is most common where a strip of varying width of this forest type occurs along the western edge of the Aravalli Mountains. However, very arid fragmented thorny forest comprised largely of sparse, low vegetation in the far western region of the state is devoid of these arboreal lizards.

Although arboreal and cryptic, chameleons are well known in Rajasthan, where a number of vernacular names (Table 2) accurately describe the animal and its behavior. A number of superstitions regarding to these lizards exist among the Kathodi. For instance, if a pregnant Kathodi woman sees a chameleon, she will give birth to an ugly child. The tribe 
Table 1. Sites in Rajasthan, India, where Asian Chamaeleons (Chamaeleo zeylanicus) are know to occur. Site numbers correspond to districts marked in Fig. 2. Forest types: A = Group 5 - Tropical dry deciduous forest; B = Group 6-Tropical thorn forest; C = Group $8-$ Subtropical broad-hill forest.

\begin{tabular}{|c|c|c|c|}
\hline Site (District) & Location & References & Forest type \\
\hline 1 (Nagaur) & Nimod Village and other parts of the district & Sharma et al. 2016 & $\mathrm{~B}$ \\
\hline \multirow[t]{2}{*}{2 (Sirohi) } & Mt. Abu & D'Souza 1978; Sharma 2001 & $\mathrm{C}$ \\
\hline & Morus Reserve Forest near Rameshvarum Temple & Present study & A \\
\hline \multirow[t]{2}{*}{3 (Pali) } & Dururi Area & Bhatnagar and Mahur 2008 & B \\
\hline & Ranakpur, Parshuram Mahadev, Desuri & Present study & A, B \\
\hline \multirow[t]{8}{*}{4 (Udaipur) } & Sajjangarh Wildlife Sanctuary & Sharma 1999 & A, B \\
\hline & Jaisamand Wildlife Sanctuary & Sharma 2014 & $A, B$ \\
\hline & Baghdarah Nature Park & Bhatnagar and Mahur 2008 & $\mathrm{~A}, \mathrm{~B}$ \\
\hline & Phulwari-ki-nal Wildlife Sanctuary & Sharma 1997 & A \\
\hline & Ogna, Falasiya, Adkailiya, Nala, Patiyam, Som Ghata, & Present study & A \\
\hline & Ramkunda, Samoli, Dhala, Kolyari, Kamalnath, Keoda & & \\
\hline & ki nal, Khokhariya ki nal, Sayra, Bokhada (Khumbhalgarh & & \\
\hline & Wildlife Sanctuary) & & \\
\hline 5 (Banswara) & Kela pani, Kushalgarh & Present study & A \\
\hline \multirow[t]{3}{*}{6 (Dungarpur) } & Near Modimata Temple, Forest Range Antrii; Rata Pani & Virendra Singh Bedsa, pers. comm. 2016; & A \\
\hline & and Rani Jhula Forest Block, Forest Range Dungarpur; & D.S. Rathore, ACF, 2016 & \\
\hline & Ratanpur, Range Bichiwada & Present study & A \\
\hline \multirow[t]{2}{*}{7 (Jaipur) } & Nahargarh Wildlife Sanctuary & Sharma 2000 & A, B \\
\hline & Jamwa Ramgarh Wildlife Sanctuary & Present study & $A, B$ \\
\hline \multirow[t]{2}{*}{8 (Pratapgarh) } & Arnod & Sh. Udairam Jat, ACF, pers. comm. 2016 & A \\
\hline & Sitamata Wildlife Sanctuary & Bhatnagar et al. 2010 & A \\
\hline 9 (Chittorgarh) & Choti Sadri and Badi Sadri & Present study & A \\
\hline \multirow[t]{2}{*}{10 (Rajasmand) } & Kumbhalgarh (Kumbhalgarh Wildlife Sanctuary), & Present study & A, B \\
\hline & Charbhuja, Jhilwara & & \\
\hline \multirow[t]{2}{*}{11 (Sikar) } & Sanwali Village near Dujodh Village (dead-on-road near & Present study & $\mathrm{B}$ \\
\hline & Sikar City during rainy season in 1999) & & \\
\hline 12 (Ajmer) & Jawaja & Present study & B \\
\hline
\end{tabular}

also believes that these animals are poisonous and avoid them whenever they are encountered. When encountered on the ground during breeding season (monsoon period), fearful tribal people kill them. Roadkills also threaten these slowmoving creatures as wide multi-lane roads and fast-moving vehicles lead to high chameleon mortality rates.

\section{Acknowledgments}

We thank the officials of the various forest divisions and the headmen of various tribal villages for facilitating our study.

\section{Literature Cited}

Bhatnagar, C. and M. Mahur. 2008. Reptilian fauna of Baghdarrah Nature Park, Udaipur Wildlife Division, Udaipur, Rajasthan, India. Cobra 3(2): 18-20
Bhatnagar, C., V.K. Koli, S.K. Sharma, R. Salvi, and M. Yaseen. 2010. An annotated checklist of reptilian fauna of Sitamata Wildlife Sanctuary, Rajasthan, India. Cobra 4(2): 16-19.

Champion, H.G. and S.K. Seth. 1968. A Revised Study of the Forest Types of India. Government of India, New Delhi.

D'Souza, D. 1978. Bird watching in Mt. Abu. Newsletter for Birdwatchers 18(9): 7.

Gaur, S. 2004. Discovery of the Indian Chamaeleon (Chamaeleo zeylanicus Laurenti) in the Aravalli foothills of Rajasthan. Tigerpaper 31(3): 1-3.

Sharma, S.K. 1997. Herpetofauna of Phulwari-ki-nal Wildlife Sanctuary, Rajasthan State. Journal of the Bombay Natural History Society 94: 573-575.

Sharma, S.K. 1999. Reptilian and amphibian fauna of Sajjangarh Wildlife Sanctuary, Udaipur, Rajasthan. Cobra 38:14-15.

Sharma, S.K. 2000. A preliminary report on the herpetofauna of Nahargarh Wildlife Sanctuary, Jaipur District, Rajasthan, India. Cobra 41: 2-7.

Sharma, S.K. 2001. Preliminary survey of the reptilian fauna of Mount Abu Wildlife Sanctuary and snake conservation effort in Mount Abu town. Cobra 44: 5-10. 
Table 2. Vernacular names for Asian Chameleons (Chamaeleo zeylanicus) in Rajasthan, India.

\begin{tabular}{|c|c|c|c|}
\hline District (location) & Tribe/Community & Vernacular names & Etymology \\
\hline Udaipur (Udaipur) & $\begin{array}{l}\text { Bhil, Garasia, } \\
\text { Damor, Kathodi }\end{array}$ & $\begin{array}{l}\text { Halanviya, Halniya, Halanmera, } \\
\text { Leelo Kachindo, Peeye }\end{array}$ & $\begin{array}{l}\text { From hilna = moving in a to-and-fro } \\
\text { swinging manner }\end{array}$ \\
\hline Sikar (Sanwali Village) & All sects & Ichhadgawa & $\begin{array}{l}\text { From ichhadgawa chaal (i.e., chameleon walk) } \\
\text { = walking in a "humpty-dumpty" manner }\end{array}$ \\
\hline Banswara (Kushalgarh) & Bhil, Bhil Meena & Halarmeha & From hilna (see above) \\
\hline Jaipur (Jamwa Ramgarh) & Meena & Reengangora, Reenganghoda & $\begin{array}{l}\text { From reengana }=\text { crawling and ghoda }=\text { horse } \\
\text { (i.e., a crawling horse) }\end{array}$ \\
\hline Pali (Pali) & All sects & Khad Kakeda & $\begin{array}{l}\text { From } k h a d=\text { jungle and } \\
\text { kakeda }=\text { garden lizard }\end{array}$ \\
\hline
\end{tabular}

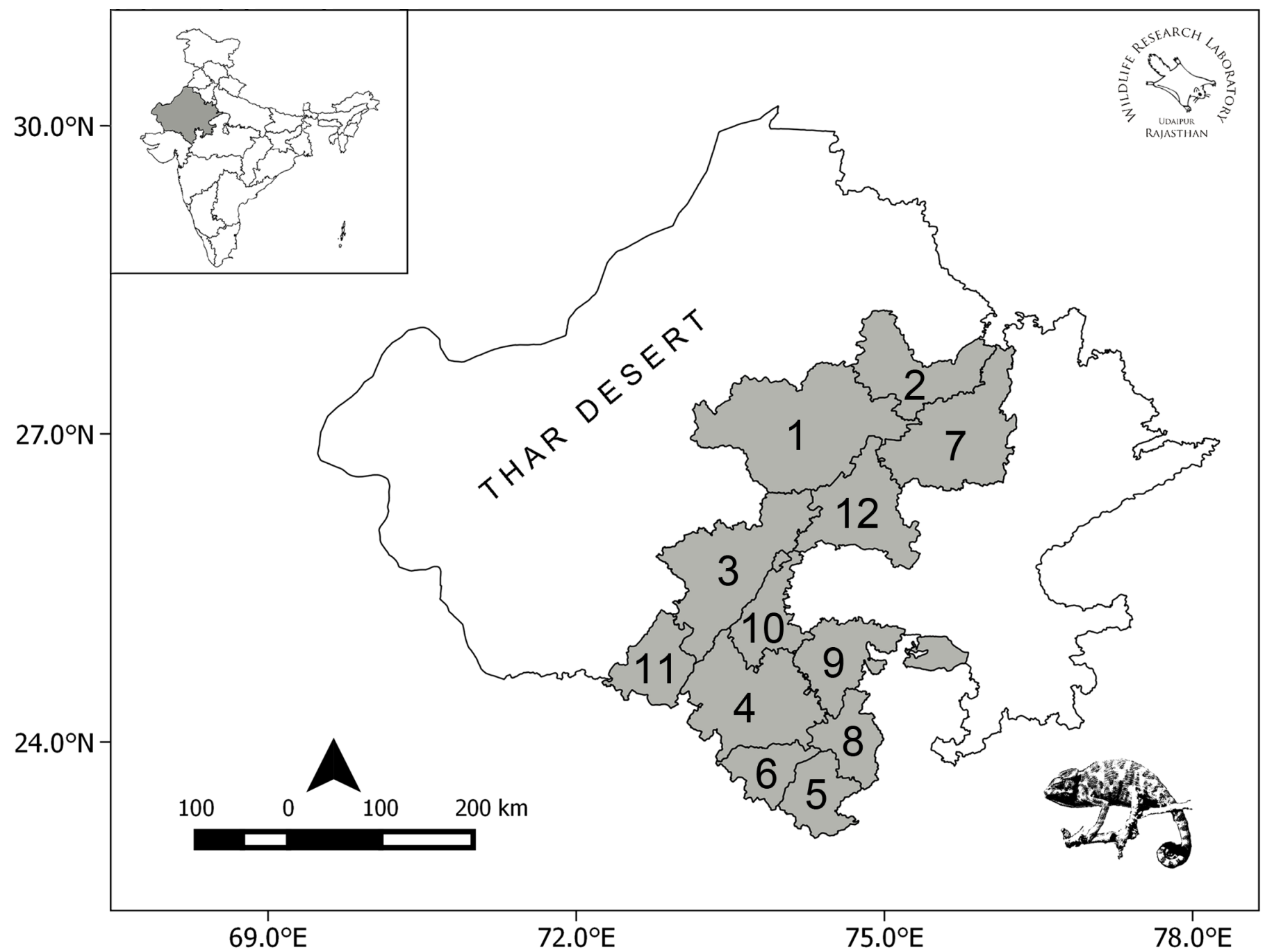

Fig. 2. Twelve districts in Rajasthan, India, where Asian Chameleons (Chamaeleo zeylanicus) have been recorded. See Table 1 for District numbers.

Sharma, S.K. 2014. Herpetofauna of Jaisamand Wildlife Sanctuary. Cobra 8(1): 21-25.

Sharma, V., S. Neha, K. Jugal, B.L. Jangir, and K.K. Sharma. 2011. New localities records of Chamaeleo zeylanicus (Laurenti) from certain semi-arid areas of the Thar Desert of Rajasthan, India. Herpetology Notes 4: 287-289.

Sharma, V., K. Jugal, D. Omveer, T. Joshi, P. Sonu, and K.K. Sharma. 2016.
Herpetofaunal checklist of Nagaur, Rajasthan. Cobra 10(1): 9-14.

Srinivasulu, C., B. Srinivasulu, P. Mohapatra, G. Shankar, A. Das, B.H.C.K. Murthy, A. Aengals, and R. Somaweera. 2014. Chamaeleo zeylanicus. The IUCN Red List of Threatened Species 2014: e.T172657A1360663.

Tikader, B.K. and R.C. Sharma. 1992. Handbook of Indian Lizards. ZSI, Calcutta, India. 